\title{
Assessment of Knowledge and Attitude towards Hepatitis B Infection among Health-Care Professionals in a North Indian City
}

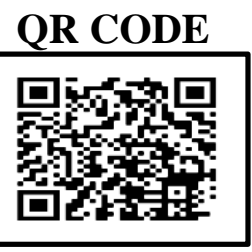

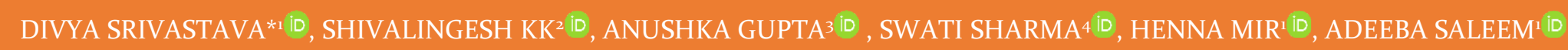

INTRODUCTION: Hepatitis B is an infection which occurs frequently worldwide. Hepatitis B virus is a DNA virus and is etiologically related to family Hepadnaviridae. Most of the cases of Hepatitis B virus infection do not have any symptoms when they are newly or chronically infected due to which there is silent spread of the infection which later causes serious liver disease. Incidence of the Hepatitis $B$ virus infection among health-care professionals has been estimated to be 2-4 times more as compared to the general population. AIMS: to assess the knowledge and attitude towards Hepatitis B infection among medical, dental, and nursing students in Bareilly city. MATERIALS AND METHOD: A cross-sectional observational study was conducted among the medical and nursing students of Rohilkhand Medical College and Hospital and dental students of Institute of Dental Sciences, Bareilly through a self-reported questionnaire was distributed among all the students of the study who were present at the day. Statistical analysis used: p-value was calculated using Kruskal Walli's ANOVA test. A p-value of 0.05 or less was used as cut off level for statistical significance.

RESULTS: Total 222 students were selected out of which 60 were medical, 60 were dental and 102 were nursing. In our study medical students had better knowledge, attitude towards Hepatitis B infection than dental and nursing students.

CONCLUSIONS: None of the students of medical, dental, and nursing were fully aware on all aspects of Hepatitis B Virus infection and the vaccination status was found to be unsatisfactory which increased the risk to acquire Hepatitis B infection.

KEYWORDS: Knowledge, Hepatitis B, Health-care Professionals.

\section{INTRODUCTION}

Hepatitis $B$ is an infection which occurs frequently worldwide. Hepatitis B virus is a DNA virus and is etiologically related to family Hepadnaviridae.

Most of the cases of Hepatitis B virus infection do not have any symptoms when they are newly or chronically infected due to which there is silent spread of the infection which later causes serious liver disease. Every year about 10 lakh people die from this infection notwithstanding the fact that this infection could be prevented.

At present there are five identified viruses (hepatitis A, B, C, D and E) that specifically attack the liver to cause "viral hepatitis" or inflammation of the liver. Among all of the hepatitis viruses only the hepatitis B and C viruses result in "chronic" infection that may further lead to cirrhosis, liver cancer and liver failure.

Hepatitis B virus may remain inactive or cause significant liver disease (chronic carrier state) such as liver fibrosis, cirrhosis and finally terminal stage liver disease. ${ }^{1}$

Hepatitis B virus is able to survive outside the human body for at least seven days but can still cause infection during this time period. The incubation period of the hepatitis B virus is 30 to 180 days and it can be detected within 30 to 60 days after infection.

Hepatitis B is most commonly spread through perinatal transmission i.e. from mother to child, or through horizontal transmission by exposure to infected blood. Chronic hepatitis B virus infection is very commonly seen in infants who have been infected from their mothers or infected otherwise.

The mode of spread can also be through exposure to infected blood and body fluids, such as saliva, semen and vaginal fluids and also by piercing, needlestick injury and tattooing.

Health-care workers are more knowledgeable than general population about the various infections and 
preventive measures to control them as they are being regularly trained. ${ }^{2}$

Incidence of the Hepatitis B virus infection among health-care professionals has been estimated to be $2-4$ times more as compared to the general population. ${ }^{3}$

In hospital setup, Hepatitis B infection can be transmitted to medical, dental and nursing students through contact with blood or saliva of infected patients during treatment procedures, while drawing blood, giving injections, or suturing, and needlestick injuries sustained while performing the procedures. Hence from the view-point of occupational safety measures, all health-care workers should be vaccinated against Hepatitis B Virus. ${ }^{4}$

Hence, this study was conducted to assess the knowledge and attitude regarding HBV infection among health-care professionals in Bareilly city.

\section{MATERIALS AND METHOD}

A cross-sectional observational study was conducted among the medical and nursing students of Rohilkhand Medical College and Hospital and dental students of Institute of Dental Sciences, Bareilly.

Stratified random sampling method was done for selection of students. There were three natural groups - medical, dental and nursing students. The students were grouped by course as MBBS, BDS, and nursing then they were selected from each group by simple random method. The study subjects were made fully aware about the nature of the study and its design. Verbal informed consent was obtained and anonymity of the study participants was maintained throughout the study.

Total sample size taken was 222 out of which 60 were medical, 6o were dental and 102 were nursing students. A self-reported questionnaire was distributed among all the students of the study who were present at the day. The questionnaire was adapted from pre-tested and pre-validated questionnaires from previous studies.

The questionnaire included questions on various aspects of hepatitis B infection on knowledge and attitude towards hepatitis B infected patients.

The subjects were asked to mark one of the most appropriate answers for each question.
The data collected was entered in to the Microsoft Excel Sheet then the total number of responses was calculated and compared. p-value was calculated using Kruskal Walli's ANOVA test.

A p-value of 0.05 or less was used as cut off level for statistical significance.

\section{RESULTS}

The present study was conducted among 222 participants out of which 162 were females and 6o were males. (Table 1) Mean age of the study population was 20.5 years.

\begin{tabular}{|c|c|c|c|c|c|}
\hline \multicolumn{2}{|c|}{ MEDICAL } & \multicolumn{2}{|c|}{ DENTAL } & \multicolumn{2}{|c|}{ NURSING } \\
\hline M & $\mathbf{F}$ & M & $\mathbf{F}$ & M & $\mathbf{F}$ \\
\hline 36 & 24 & 13 & 47 & 11 & 91 \\
\hline & & $\begin{array}{l}\mathrm{r}-\mathrm{V} \\
\mathrm{ts}(\mathrm{l}\end{array}$ & ales & $\begin{array}{l}\text { o } \\
\text { mal }\end{array}$ & \\
\hline
\end{tabular}

The knowledge and attitude responses of the medical, dental, and nursing students has been listed in in Table 2,3 , and 4 .

Knowledge on hepatitis B: Results revealed that all the responders $(100 \%)$ had heard of hepatitis B infection. When queried about the spread of hepatitis B, $23.3 \%$ of the medical students, $30 \%$ of the dental students, and $28.4 \%$ of the nursing students stated that hepatitis B was spread by blood transfusion, $36.7 \%$ of the medical students, $35 \%$ of the dental students, and $36.3 \%$ of the nursing students were of the opinion that it was spread by contaminated needles, $35 \%$ of the medical, $26.7 \%$ dental, and $26.5 \%$ nursing students concurred that it was spread by exposure to infected body fluids.

All of the participants (93.1\%) believed that it was a viral infection except $6.9 \%$ of the nursing students who believed that it was a bacterial infection which was statistically significant.

$86.7 \%$ of medical, $96.7 \%$ dental students believed that hepatitis B was life threatening but only $79.4 \%$ of the nursing students believed so which was statistically significant.

On whether they knew other types of hepatitis infections, $1.7 \%$ of medical, $5 \%$ of dental students were 


\begin{tabular}{|c|c|c|c|c|c|c|c|c|}
\hline \multirow{3}{*}{$\begin{array}{c}\text { Have you heard of } \\
\text { hepatitis B? }\end{array}$} & \multirow[b]{2}{*}{ Yes } & \multicolumn{2}{|c|}{ MEDICAL } & \multicolumn{2}{|c|}{ DENTAL } & \multicolumn{2}{|c|}{ NURSING } & \multirow{3}{*}{$\begin{array}{r}\mathrm{p} \text { value } \\
1.000\end{array}$} \\
\hline & & 60 & $(100 \%)$ & 60 & $(100 \%)$ & 102 & $(100 \%)$ & \\
\hline & No & o & (o\%) & o & (o\%) & o & (o\%) & \\
\hline \multirow{9}{*}{$\begin{array}{l}\text { Hepatitis B is spread } \\
\text { by }\end{array}$} & Blood transfusion & 14 & $(23.3 \%)$ & 18 & $(30 \%)$ & 29 & $(28.4 \%)$ & \multirow{9}{*}{0.797} \\
\hline & Contaminated needles & 22 & $(36.7 \%)$ & 21 & $(35 \%)$ & 37 & $(36.3 \%)$ & \\
\hline & Exposure to infected body fluids & 21 & $(35 \%)$ & 16 & $(26.7 \%)$ & 27 & $(26.5 \%)$ & \\
\hline & Food prepared by infected persons & o & $(\mathrm{o} \%)$ & o & $(0 \%)$ & o & $(\mathrm{o} \%)$ & \\
\hline & Shaking hands with infected persons & o & $(\mathrm{o} \%)$ & o & $(0 \%)$ & o & (o\%) & \\
\hline & Use of infected razors & o & (o\%) & o & (o\%) & o & (o\%) & \\
\hline & $\begin{array}{c}\text { Vertical transmission from mother to } \\
\text { child }\end{array}$ & o & $(\mathrm{o} \%)$ & 1 & $(1.7 \%)$ & o & $(\mathrm{o} \%)$ & \\
\hline & Sexual intercourse & 3 & (5\%) & 4 & $(6.7 \%)$ & 9 & $(8.8 \%)$ & \\
\hline & Coughing & o & (o\%) & o & $(0 \%)$ & o & $(0 \%)$ & \\
\hline \multirow{3}{*}{$\begin{array}{l}\text { Hepatitis B is a } \\
\text { infection? }\end{array}$} & Viral & 60 & $(100 \%)$ & 60 & $(100 \%)$ & 95 & $(93.1 \%)$ & \multirow[t]{3}{*}{$0.015^{*}$} \\
\hline & Bacterial & o & (o\%) & o & $(0 \%)$ & 7 & $(6.9 \%)$ & \\
\hline & Parasitic & o & (o\%) & o & (o\%) & o & (o\%) & \\
\hline \multirow{2}{*}{$\begin{array}{l}\text { Hepatitis B is life } \\
\text { threatening? }\end{array}$} & Yes & 52 & $(86.7 \%)$ & 58 & $(96.7 \%)$ & 81 & $(79.4 \%)$ & \multirow[t]{2}{*}{$0.009^{*}$} \\
\hline & No & 8 & $(13.3 \%)$ & 2 & $(3.3 \%)$ & 21 & $(20.6 \%)$ & \\
\hline \multirow{2}{*}{$\begin{array}{c}\text { Have you heard of } \\
\text { other types of } \\
\text { hepatitis infections? }\end{array}$} & Yes & 59 & $(98.3 \%)$ & 57 & $(95 \%)$ & 86 & $(84.3 \%)$ & \multirow[b]{2}{*}{$0.005^{*}$} \\
\hline & No & 1 & $(1.7 \%)$ & 3 & $(5 \%)$ & 16 & $(15.7 \%)$ & \\
\hline \multirow{2}{*}{$\begin{array}{c}\text { Does hepatitis B } \\
\text { infection lead to } \\
\text { other types of } \\
\text { hepatitis infections? }\end{array}$} & Yes & 26 & $(43.3 \%)$ & 43 & $(71.7 \%)$ & 71 & $(69.6 \%)$ & \multirow[b]{2}{*}{$0.001^{*}$} \\
\hline & No & 34 & $(56.7 \%)$ & 17 & $(28.3 \%)$ & 31 & $(30.4 \%)$ & \\
\hline \multirow{3}{*}{$\begin{array}{l}\text { How do you screen } \\
\text { for hepatitis B } \\
\text { infection? }\end{array}$} & $\mathrm{HBsAg}$ & 59 & $(98.3 \%)$ & 51 & $(85 \%)$ & 47 & $(46.1 \%)$ & \multirow{3}{*}{$0.000^{*}$} \\
\hline & Anti-HBC & 1 & $(1.7 \%)$ & 6 & $(10 \%)$ & 26 & $(25.5 \%)$ & \\
\hline & Anti-HBE & o & $(\mathrm{o} \%)$ & 3 & $(5 \%)$ & 29 & $(28.4 \%)$ & \\
\hline \multirow{5}{*}{$\begin{array}{l}\text { Chronic hepatitis B } \\
\text { infection can lead to }\end{array}$} & Cirrhosis & 35 & $(58.3 \%)$ & 26 & $(43.3 \%)$ & 46 & $(45.1 \%)$ & \multirow{5}{*}{0.165} \\
\hline & Carcinoma Liver & 6 & $(10 \%)$ & 7 & $(11.7 \%)$ & 22 & $(21.6 \%)$ & \\
\hline & Kidney disease & o & $(\mathrm{o} \%)$ & o & $(\mathrm{o} \%)$ & 10 & $(9.8 \%)$ & \\
\hline & Other liver disease & 17 & $(28.3 \%)$ & 20 & $(33 \cdot 3 \%)$ & 15 & $(14.7 \%)$ & \\
\hline & Death & 2 & $(3.3 \%)$ & 7 & $(11.7 \%)$ & 9 & $(8.8 \%)$ & \\
\hline
\end{tabular}

Table 2. Knowledge of Hepatitis B among the Study Population

unaware of other type of hepatitis infections whereas $15.7 \%$ of the nursing students were unaware regarding the same which was statistically significant.

98.3\% medical and 85\% dental students had correct knowledge regarding screening of hepatitis B infection but only $46.1 \%$ nursing students were aware of the same and again this difference was statistically significant.

Only $28.3 \%$ dental, and $30.4 \%$ of the nursing students were unaware of the fact that hepatitis B infection could lead to other types of hepatitis infection whereas more than half of the medical respondents $(56.7 \%)$ were unaware of the same. $(\mathrm{p}<\mathrm{o.oo1})$

When asked about complications of chronic hepatitis B, $58.3 \%$ medical, $43.3 \%$ dental, and $45.1 \%$ of nursing students responded that chronic hepatitis B infection lead to cirrhosis and $10 \%$ of the medical, $11.7 \%$ dental, and $21.6 \%$ of the nursing students be vaccinated for hepatitis B. Only $91 \%$ of the nursing students agreed that adults had to be vaccinated for hepatitis B which was statistically significant.

Most of the medical (75\%) and dental (71.7\%) students were completely vaccinated against hepatitis B while 


\begin{tabular}{|c|c|c|c|c|c|c|c|c|}
\hline & & \multicolumn{2}{|c|}{ MEDICAL } & \multicolumn{2}{|c|}{ DENTAL } & \multicolumn{2}{|c|}{ NURSING } & $\mathbf{p}$ \\
\hline \multirow{2}{*}{$\begin{array}{l}\text { Is Hepatitis B } \\
\text { preventable? }\end{array}$} & Yes & 55 & $(91.7 \%)$ & 55 & $(91.7 \%)$ & 69 & $(67.6 \%)$ & \multirow[b]{2}{*}{$0.000^{*}$} \\
\hline & No & 5 & $(8.3 \%)$ & 5 & $(8.3 \%)$ & 33 & $(32.4 \%)$ & \\
\hline \multirow{2}{*}{$\begin{array}{c}\text { Are you aware of } \\
\text { hepatitis B vaccine? }\end{array}$} & Yes & 60 & $(100 \%)$ & 60 & $(100 \%)$ & 89 & $(87 \cdot 3 \%)$ & \multirow[t]{2}{*}{$0.000^{*}$} \\
\hline & No & o & $(0 \%)$ & o & $(0 \%)$ & 13 & $(12.7 \%)$ & \\
\hline \multirow{2}{*}{$\begin{array}{c}\text { Whether adults need } \\
\text { to be vaccinated for } \\
\text { hepatitis B? }\end{array}$} & Yes & 60 & $(100 \%)$ & 60 & $(100 \%)$ & 91 & $(89.2 \%)$ & \multirow[b]{2}{*}{$0.001^{*}$} \\
\hline & No & o & $(\mathrm{o} \%)$ & o & $(0 \%)$ & 11 & $(10.8 \%)$ & \\
\hline \multirow{2}{*}{$\begin{array}{c}\text { Whether children } \\
\text { need to be vaccinated } \\
\text { for hepatitis } B \text { ? }\end{array}$} & Yes & 59 & $(98.3 \%)$ & 60 & $(100 \%)$ & 97 & $(95.1 \%)$ & \multirow[b]{2}{*}{0.152} \\
\hline & No & 1 & $(1.7 \%)$ & o & $(0 \%)$ & 5 & $(4.9 \%)$ & \\
\hline \multirow{3}{*}{$\begin{array}{c}\text { Have you been } \\
\text { immunized with } \\
\text { hepatitis B vaccine? }\end{array}$} & Yes & 45 & $(75 \%)$ & 43 & $(71.7 \%)$ & 47 & $(46.1 \%)$ & \multirow{3}{*}{$0.000^{*}$} \\
\hline & No & 10 & $(16.7 \%)$ & 10 & $(16.7 \%)$ & 37 & $(36.3 \%)$ & \\
\hline & Unsure & 5 & $(8.3 \%)$ & 7 & $(11.7 \%)$ & 18 & $(17.6 \%)$ & \\
\hline
\end{tabular}

Table 3. Knowledge on Prevention of Hepatitis B among Study Population

only $46.1 \%$ of nursing students had done so which was again statistically significant.

Attitude towards hepatitis B infected patients: $73.3 \%$ medical, $66.7 \%$ dental and $68.6 \%$ of nursing students accepted that hepatitis $B$ patients could be allowed to work routinely.

$25 \%$ medical, $35 \%$ dental, and $13.7 \%$ of the nursing students believed that hepatitis $B$ infected patients could perform strenuous exercise. $(\mathrm{p}=\mathrm{o.013})$

$75 \%$ medical, $68.3 \%$ dental, and $81.4 \%$ of the nursing students were of the view that hepatitis B infected patients should abandon sexual contact to prevent transmission of infection to their partners.

Around $25 \%$ medical and $45 \%$ dental students believed that medical personnel should refrain from treating patients infected with hepatitis B whilst only $12.8 \%$ of the nursing students opined so which was statistically significant.

Furthermore, $81.7 \%$ of medical, $72.5 \%$ of nursing, and $61.7 \%$ of dental students were of the view that medical students could be encouraged to take the vaccine through media awareness programs and the difference was found to be statistically significant.

\section{DISCUSSION}

Outcome of the Hepatitis B infection is dependent on the result of dynamic interaction between the virus, host response and hepatocytes. ${ }^{6}$

Medical, dental, and nursing students are exposed to the occupational risk as they are the first line of of contact between patients and medical care and hence are susceptible to infected patients and contaminated instruments. Naturally they are envisioned to perform activities related to preventive care in their formative years. It is imperative to bring the relative incidence of Hepatitis B infection down by proper education regarding its transmission and by immunization of all related health care personnel with the vaccine.

This study sought to evaluate the knowledge and attitudes towards hepatitis B infection among medical and nursing students of Rohilkhand Medical College and Hospital and dental students of Institute of Dental Sciences, Bareilly.

The results of the study showed good overall knowledge and attitude about hepatitis B infection among medical and dental students but was poor among nursing respondents. The reason for this may be due to the fact that since they were not required to diagnose Hepatitis B infection, much attention was not paid to this aspect. Still, it was an important aspect to prevent oneself from acquiring it.

When asked about knowledge of Hepatitis B infection like type of infection, whether it was preventable and whether they knew other types of Hepatitis infection, nursing students scored poorly when compared with 


\begin{tabular}{|c|c|c|c|c|c|c|c|c|}
\hline \multirow{3}{*}{$\begin{array}{c}\text { Whether hepatitis B } \\
\text { patients can be } \\
\text { allowed to work } \\
\text { routinely? }\end{array}$} & \multirow[b]{2}{*}{ Yes } & \multicolumn{2}{|c|}{ MEDICAL } & \multicolumn{2}{|c|}{ DENTAL } & \multicolumn{2}{|c|}{ NURSING } & \multirow{3}{*}{$\begin{array}{l}\mathrm{P} \\
\text { value } \\
0.714\end{array}$} \\
\hline & & 44 & $(73.3 \%)$ & 40 & $(66.7 \%)$ & 70 & $(68.6 \%)$ & \\
\hline & No & 16 & $(26.7 \%)$ & 20 & $(33.3 \%)$ & 32 & (31.4\%) & \\
\hline \multirow{2}{*}{$\begin{array}{l}\text { Whether hepatitis B } \\
\text { patients can be } \\
\text { allowed to do } \\
\text { strenuous exercise? }\end{array}$} & Yes & 15 & $(25 \%)$ & 21 & $(35 \%)$ & 14 & $(13.7 \%)$ & \multirow[b]{2}{*}{$0.013^{*}$} \\
\hline & No & 45 & $(75 \%)$ & 39 & $(65 \%)$ & 88 & $(86.3 \%)$ & \\
\hline \multirow{2}{*}{$\begin{array}{l}\text { Whether hepatitis B } \\
\text { patients should } \\
\text { abandon sexual } \\
\text { contact? }\end{array}$} & Yes & 45 & $(75 \%)$ & 41 & $(68.3 \%)$ & 83 & $(81.4 \%)$ & \multirow[t]{2}{*}{0.167} \\
\hline & No & 15 & $(25 \%)$ & 19 & $(31.7 \%)$ & 19 & $(18.6 \%)$ & \\
\hline \multirow{2}{*}{$\begin{array}{l}\text { Whether medical } \\
\text { personnel should } \\
\text { refrain from treating } \\
\text { patients infected } \\
\text { with hepatitis B? }\end{array}$} & Yes & 15 & $(25 \%)$ & 27 & $(45 \%)$ & 13 & $(12.7 \%)$ & \multirow[b]{2}{*}{$0.000^{*}$} \\
\hline & No & 45 & $(75 \%)$ & 33 & $(55 \%)$ & 89 & $(87.3 \%)$ & \\
\hline \multirow{2}{*}{$\begin{array}{l}\text { How can medical } \\
\text { students be } \\
\text { encouraged to take } \\
\text { the vaccine? }\end{array}$} & Media awareness programs & 49 & $(81.7 \%)$ & 37 & $(61.7 \%)$ & 74 & $(72.5 \%)$ & \multirow[b]{2}{*}{$0.051^{*}$} \\
\hline & Others & 11 & $(18.3 \%)$ & 23 & $(38.3 \%)$ & 28 & $(27.5 \%)$ & \\
\hline
\end{tabular}

Table 4. Attitude towards Hepatitis B Infected Patients; p<0.05: statistically significant, Kruskal Wallis ANOVA

dental and medical students.

When asked whether Hepatitis B was life threatening, and its complications, dental students had marginally better knowledge when compared to medical students which is in agreement with the study conducted by Tirounilacandin et al. where dental interns $(34.7 \%)$ had better knowledge as compared to medical interns $(32.8 \%)^{7}$

Majority of medical, dental and nursing students believed that Hepatitis B was spread by exposure to infected blood \& body fluids which was similar to a study conducted in BJ Medical College, Gujarat that also showed a high level of knowledge (86.7\%) regarding modes of transmission. ${ }^{8}$ Contrarily, a study conducted by Paul P et al. in Tagore medical college and hospital, Chennai showed low level of knowledge regarding transmission. ${ }^{5}$

Majority of medical and dental students were aware about the screening for hepatitis B infection whereas only $46.1 \%$ of the nursing students had the awareness regarding the same which was statistically significant. This is in contrary to the study conducted by Paul P et al. where only $50.8 \%$ of the medical and dental students knew the correct answer. 5
When asked about complications of Hepatitis B, the results showed very less knowledge among medical, dental, and nursing students which was in agreement to a study conducted by Paul $P$ et al. in which very less respondents had correct knowledge. ${ }^{5}$

With regard to the vaccination status, higher proportion of medical students received vaccination as compared to dental and nursing students which was in contrast with the study conducted by Adenlewo et al. in Nigerian university where dental students (88.71\%) received the vaccine more than medical students $(76.47 \%)$ and the reason for not getting vaccinated was considered to be their busy schedule. ${ }^{9}$

In an Ethiopian study, $13.4 \%$ of the students received one or more doses of hepatitis B vaccine but only $4.7 \%$ of the students were fully vaccinated against Hepatitis B. ${ }^{10}$

The vaccination status in Muhammad medical college Mirpurkhas, was $87.8 \%, 1129.3 \%$ in medical students of BJ medical college, $8 \quad 42 \%$ in medical students of Lahore. ${ }^{12}$

When asked whether hepatitis B patients can be allowed to work routinely and perform strenuous 
exercise and whether medical personnel should refrain from treating Hepatitis B infected patients, nursing students scored better as compared to medical and dental students.

In our study medical students had better knowledge and attitude towards Hepatitis B infection than dental and nursing students.

Based on the results from this study, we can infer that there is a further need to improve knowledge about Hepatitis B Virus infection in medical, dental, and nursing students.

\section{CONCLUSION}

This study concludes that none of the students of medical, dental, and nursing were fully aware on all aspects of HBV infection and the vaccination status was found to be unsatisfactory which increased the students' risk to acquire Hepatitis B infection. Hence, we need a regular con $\neg$ tinuing awareness program for all the students and it is recommended that schedule for Hepatitis B vaccination be made compulsory for all the students in the first year of their college.

\section{REFERENCES}

1. Kuriakose M, Ittyachen AM. An Investigation into the High Prevalence of Hepatitis B in a Rural Area of Kerala State, India: Hypothesis on Chrysops sp. (Diptera: Tabanidae) Transmission. Biomedical Research International 2018;2018(1):1-7.

2. Kashyap B, Tiwari U, Prakash A. Hepatitis B virus transmission and health-care workers: Prevention, management, and awareness toward the disease. Indian Journal of Medical Specialities 2019;10(1):6-11.

3. Pruss-Ustun A, Rapiti E, Hutin Y. Estimation of the global burden of disease attributable to contaminated sharps injuries among health-care workers. American Journal of Industrial Medicine 2005;48(6):482-90.

4. West DJ. The risk of hepatitis B infection among health pro-fessionals in the United States: a review. American Journal of the Medical Sciences 1984;287(2):26-33.

5. Paul P, Arumugam B. Knowledge and awareness regarding hepatitis $\mathrm{B}$ infection among medical and dental students: a comparative cross sectional study. International Journal of Research in Medical Sciences 2015;3(9):2352-6.

6. Sharma R, Sharma C L, Khajuria R. The Knowledge, Attitude and Practices regarding HBV infection of married women in reproductive age group living in cantonment area Sunjawan, Jammu, JK Science JulySept. 2004;6(3):127-30.

7. Tirounilacandin P, Krishnaraj S, Chakravarthy K. Hepatitis-B infection: Awareness among medical, dental interns in India. Annals of Tropical Medicine and Public Health 2009;2(2):33-6.

8. Singh A, Jain S. Prevention of Hepatitis B; knowledge and practices among Medical students. Healthline 2011;2(2):8-11.

9. Adenlewo OJ, Adeosun PO, Fatusi OA. Medical and dental students' attitude and practice of prevention strategies against hepatitis B virus infection in a Nigerian university. The Pan African Medical Journal 2017;28:33.

10. Mesfin YM, Kibret KT. Assessment of Knowledge and Practice towards Hepatitis B among Medical and Health Science Students in Haramaya University, Ethiopia. PLoS ONE 2013;8(11):e79642.

11. Muhammad A, Waseem R, Zulfikar AG. Hepatitis B vaccination coverage in medical students at a medical college of Mirpurkhas. Journal of Pakistan Medical Association 2011;61(7):680-2.

12. Biju IK, Sattar A, Kate M. Incidence and awareness of hepatitis B infection among paramedical students. Indian Journal of Gastroenterology 2002;21(1):104-5. 
Source of support: Nil, Conflict of interest: None declared

Cite this article as:

Srivastava D, Shivlingesh KK, Gupta A, Sharma S, Mir H, Saleem A Assessment of Knowledge and Attitude towards Hepatitis B Infection among Health-Care Professionals in a North Indian City. Int Healthc Res J 2020;3(12):383-389. https://doi.org/10.26440/IHRJ/0312.0325

\section{AUTHOR AFFILIATIONS: ( ${ }^{*}$ Corresponding Author)}

1. Post Graduate Student [ORCID IDs: https://orcid.org/oooo-00o2-1755-8436 (Dr. Divya Srivastava),

https://orcid.org/oooo-0oo2-3233-2654 (Dr. Henna Mir), https://orcid.org/oooo-ooo1-6900-o613 (Dr. Adeeba Saleem)]

2. Professor \& Head (ORCID ID: https://orcid.org/oooo-00o2-4636-522X)

3. Senior Lecturer (ORCID ID: https://orcid.org/oooo-0oo3-3791-1345)

Department of Public Health Dentistry, Institute of Dental Sciences, Bareilly, India.

4. Professor \& Head, Department of Public Health Dentistry, School of Dental Sciences, Sharda University (ORCID ID:

https://orcid.org/oooo-0oo1-7181-5299).

Contact corresponding author at: divya.sri.2311[at]gmail[dot]com 